\title{
A visualidade Háptica no Cinema de Poesia de Joel Pizzini
}

Bárbara Bergamaschi Novaes*

\begin{abstract}
RESUMO: Através de uma breve análise dos curta-metragens: Glauces - Estudo de um Rosto (2001) e Enigma de um Dia (1996) do diretor Joel Pizzini procura-se pensar as materialidades da comunicação dentro de uma corrente pós-hermenêutica. No contexto de cena ampliada e do cinema expandido que se configura a partir do trânsitos e diversidade de suportes, dispositivos e experiências, e nas multiplicidades temporais fragmentarias, vislumbramos os filmes de Pizzini como potências sensoriais e afetivas, nos focando em suas forças poéticas e plásticas, mais do que na narração ou em seus aspectos linguísticos. Para tal iremos nos utilizar das ideias presentes no livro "The Skin of the Film" da americana Laura Marks (2000), principalmente do conceito de percepção háptica - de uma percepção do olho que vê mas também toca- .descrita por autores tais como Jacques Aumont (2004) e Deleuze e Guatarri (2005) para analisar suas obras cinematográficas.
\end{abstract}

PALAVRAS-CHAVES: Cinema Experimental, Imagem Háptica, Materialidade, pós-hermeneutica, Cinema de Poesia.

ABSTRACT: This critic review of Joel Pizzini's short films operates under a posthermeneutic current of thought that turns itself to the materiality of communication. Considering the emergence of a contemporary visual production based on the autonomy of the image, focusing on its plastic and fragmentary force more than on a narrative or linguistic approach, this brief analysis will focus on the sensory and affective powers present in Pizzini's cinema work. For such analyses we will resort on the concept of "haptic perception" presente in Laura Marks (2000) book "The Skin of the Film"

KEYWORDS: Experimental Cinema, Haptic Image, Materiality, Post-Hermeneutics, Poetry Cinema.

\footnotetext{
*Bárbara Bergamaschi Novaes é formada em Comunicação Social (2014) pela Universidade Federal do Rio de Janeiro (ECO-UFRJ) com habilitação em Rádio e TV. Realizou programa de intercâmbio Acadêmico (2012) na Universidade de Paris 8 Licénce en Cinéma. Atualmente é mestranda bolsista (FAPERJ) no programa de pós-graduação de Artes das Cenas (PPGAC/ECO-UFRJ).
} 
O termo "Cinema de Poesia" se consolidou na corrente da crítica após conferência proferida por Pasolini no Festival de Pesaro, em 1966, em que o cineasta afirmou, entre outras premissas, que "o verdadeiro protagonista no Cinema de Poesia é o estilo"1. A obra de Pizzini além de possuir as características desse gênero cinematográfico - ao operar por procedimentos alegóricos, os acontecimentos se passam fora da experiência tradicional do tempo e do espaço e fogem a narrativa clássica²- é também marcada, nas palavras do diretor, por: "uma experimentação com a materialidade da imagem e um esforço na pesquisa de linguagem para dar um tratamento plástico e ressignificar material de arquivo em uma perspectiva dramática". Muitos de seus filmes se utilizam de imagens vindas de aparelhos analógicos que possuem características plásticas e estéticas peculiares deste meio como: decomposição e desgaste da película, queimaduras causadas pelo vazamento de luz, sujeira, cores esmaecidas, presença do grão de prata, bordas pretas, ruídos e outras imperfeições.

Em debate durante a $39^{a}$ Mostra de Cinema de São Paulo o cineasta afirmou:

\begin{abstract}
"A gente está sempre ligado demais ao tema, ao conteúdo, ao que vai dizer. Mas na verdade a gente tem que estar contaminado pela matéria, pela matéria onírica, como dizia o Glauber. É nela que há uma dramaticidade, uma ranhura, uma autenticidade, uma textura. Isso é muito importante. A matéria é sempre, utilizada e controlada para confirmar uma determinada visão. É sempre para apaziguar e não para causar espasmo. Eu acredito na sensualidade da matéria do cinema" (Entrevista para Carta Capital em 5/11/2015). ${ }^{3}$
\end{abstract}

Ainda em entrevista para Folha de Pernambuco neste ano o cineasta declarou :

\begin{abstract}
“Durante a pós-produção (do filme Olho Nu, biografia de Ney Matogrosso) os técnicos não entendiam que eu queria preservar a precariedade das imagens, aquela textura. Acho que ela tem uma dimensão emocional. O esforço foi como dar relevo para imagem sem que ela fosse higienizada. Essa é uma cultura que existe no documentário, deixar tudo limpo, perfeito." (Em entrevista para Folha de Pernambuco em 19/02/2016). ${ }^{4}$
\end{abstract}

Tendo em mente a definição feita por Joana Sasson (2004) que a imagem pode ser considerada como um objeto laminado de múltiplas camadas podendo ter seu sentido apreendido através do relacionamento simbólico entre três dimensões: material, conteúdo e contexto optamos por privilegiar a dimensão material nesta análise. Esta dimensão diz respeito à forma e a estética: cores, formatos, tonalidades, filtro, camadas e texturas que habitam a imagem. A 
forma como a imagem será manipulada no tempo produz diversas alterações na imagem fotográfica, bem como na película cinematográfica. Sendo manipulada e transportada a imagem fica sujeita à ação do tempo e de choques físicos: queimaduras, sujeiras, rasgos, recortes, dobraduras, falhas, envelhecimento, esmaecimento das cores - uma gama de marcas físicas do passar do tempo que formam uma espécie de "gramática", que por sua vez, interferem na leitura destas imagens. Na dimensão material nos concentramos nos elementos que compõe o corpo da imagem, percebendo a imagem como uma superfície, com características plásticas e como um objeto material.

Considerando também a premissa de Susan Sontag expressa na máxima "No lugar de uma hermenêutica precisamos de uma erótica da arte" (SONTAG, 1987) em seu texto original Against Interpretation, procura-se, em nossa análise, recuperar uma interpretação que invoca "sentidos outros", buscando assim um vocabulário mais descritivo que prescritivo e uma maior atenção à forma. Para Sontag, os "sentidos outros" (como por exemplo: tato, olfato e audição) estariam sendo relegados a segundo plano em favor de um modelo cognitivo-cartesiano que se fundamentou prioritariamente na visão como forma privilegiada para interpretar o mundo. Sontag, portanto, manifesta-se contra a interpretação assente única e exclusivamente no conteúdo da obra. O teórico e crítico literário Hans Ulrich Gumbrecht, em seu livro Produção de presença (2004) conjuga, em afinidade com as proposições de Sontag, o conceito de materialidades da comunicação na tentativa de apreender aquilo que está fora do escopo hermenêutico: "Originalmente, materialidades da comunicação eram todos aqueles fenômenos e condições que contribuem para a produção de sentido, sem serem o sentido em si." (GUMBRECHT, 2004, pg. 28).

Almeja-se, portanto, no presente artigo pensar os dois curta-metragens do diretor Joel Pizzini: Glauces - estudo de um rosto (2001) e Enigma de um dia (1996) dentro de um campo de estudo e proposta pós-hermenêuticos, onde o que importa não é a significação e o conteúdo, e sim a utilização de um vocabulário descritivo desses fenômenos físicos e sensoriais que participam na produção de sentido na dimensão material da imagem. Dentro do contexto do campo ampliado ${ }^{5}$ das artes e do "cinema expandido" ${ }^{6}$ que se configura a partir de trânsitos e diversidade de suportes, dispositivos e experiências e nas multiplicidades temporais, analisamos os filmes de Pizzini como potências sensoriais e afetivas, nos concentrando em suas forças plásticas e fragmentárias, mais do que na narrativa ou em seus aspectos linguísticos. 
Uma prática audiovisual que acredita na constituição de um novo olhar que se propõe mais livre, poético, sensorial, que invocam o conceito de visualidade háptica descrita por Jacques Aumont (1989) Deleuze e Guattari (1992), aprofundado no livro The skin of the film da autora americana Laura U. Marks (2000) de uma percepção do olho que vê mas também toca, uma visão tátil que se volta para superfície da imagem.

\section{Glauces - Estudo de um Rosto (2001)}

Glauces, é um filme-ensaio sobre a atriz Glauce Rocha, figura mitológica do cinema brasileiro. Feito a partir de uma profunda pesquisa de imagens de arquivo da filmografia de Glauce, a obra remonta mais de duas décadas de trabalhos estrelados pela atriz se valendo apenas da força das imagens e do recurso da montagem. O diretor evita o uso de ferramentas clássicas do gênero documentário como a voz off, a narração, a locução e entrevistas no estilo " talking heads".

De estrutura cíclica, o filme se inicia com a poesia escrita por Pizzini e Sérgio Medeiros, declamada por Paulo Autran, que enumera as diferentes Glauces, partindo da origem do nome na mitologia Grega, ("Glauce era noiva de Jasão, Glauce era rival de Medéia..."), bem como citando os diferentes papéis interpretados por ela ("Glauce é pureza, Sara, Soraya, Helena, Frida, Dorina, Neusa, Sueli, Glauce é Rocha"). Glauce, dessa forma, representaria a ideia universal da musa que inspira poetas, arquétipo da condição feminina pois em sua imagem estão refletidas todas as mulheres. Neste primeiro momento introdutório o rosto de Glauce Rocha não nos é apresentado, vislumbramos apenas seu corpo de costas, seus gestos, closes de mãos, silhueta, e assim, aos poucos delineia-se uma figura para encarnar o mistério: afinal quem é Glauce Rocha?

O rosto de Glauce finalmente nos é revelado junto com sua voz em off, no que parece ser um ensaio e técnica de aquecimento e/ou dublagem [como nos filmes de Fellini e retratado no clássico Cantando na chuva (1952)]. A atriz declama diversos números num crescendo na entonação e emoção. A cada número uma nova Glauce nos é apresentada sob diferentes roupagens, papéis e personagens, fragmentos costurados dos filmes de sua carreira, entre eles: Terra em transe (1967), de Glauber Rocha, Os cafajestes (1962), de Ruy Guerra, Navalha na carne (1970), de Braz Chediak e Um caso de polícia (1959), de Carla Civelli. A partir desse momento o filme se concentra, como diz seu título, em estudar o rosto de uma atriz de mil-faces. 
Glauces polimorfas e plurais trocam e entrecruzam olhares se multiplicando. Pizzini se vale do raccord na montagem como ferramenta dialógica entre os filmes, criando espaços diegéticos outros, possibilitando novas mise-en-scènes: Glauce caminha por corredores, bate e sai por diversas portas diferentes, atende ao telefone e fala consigo mesma e 'se olha" através do campo e fora-de-campo dos quadros. Aqui lembramos Pasolini sobre o Cinema de Poesia: "diferente do cinema de prosa, onde não se percebe a câmera e não se sente a montagem (em outras palavras "a língua" que está sendo utilizada na construção) no Cinema de Poesia, ao contrário, sente-se a câmera, sente-se a montagem e muito"( PASOLINI, 1982). Dentro dessa lógica, o filme de Pizzini não é apenas um filme sobre a vida de Glauce Rocha, mas uma reflexão acerca da própria representação e da imagem. A atriz, nesse sentido, percorre e atravessa "literalmente" sua carreira no cinema através do próprio meio fílmico. Uma imagem que a todo instante dobra sobre si mesma num movimento de myse-em-abyme infinito, um filme metalinguístico que engendra um olhar sobre o cinema enquanto se constitui como tal. Imagem que está diante de si, que se olha refletidas vezes em diversas superfícies, espelhos, lentes, mas que igualmente olha para além de si, para a câmera se transportando para o "fora" e para a superfície da tela.

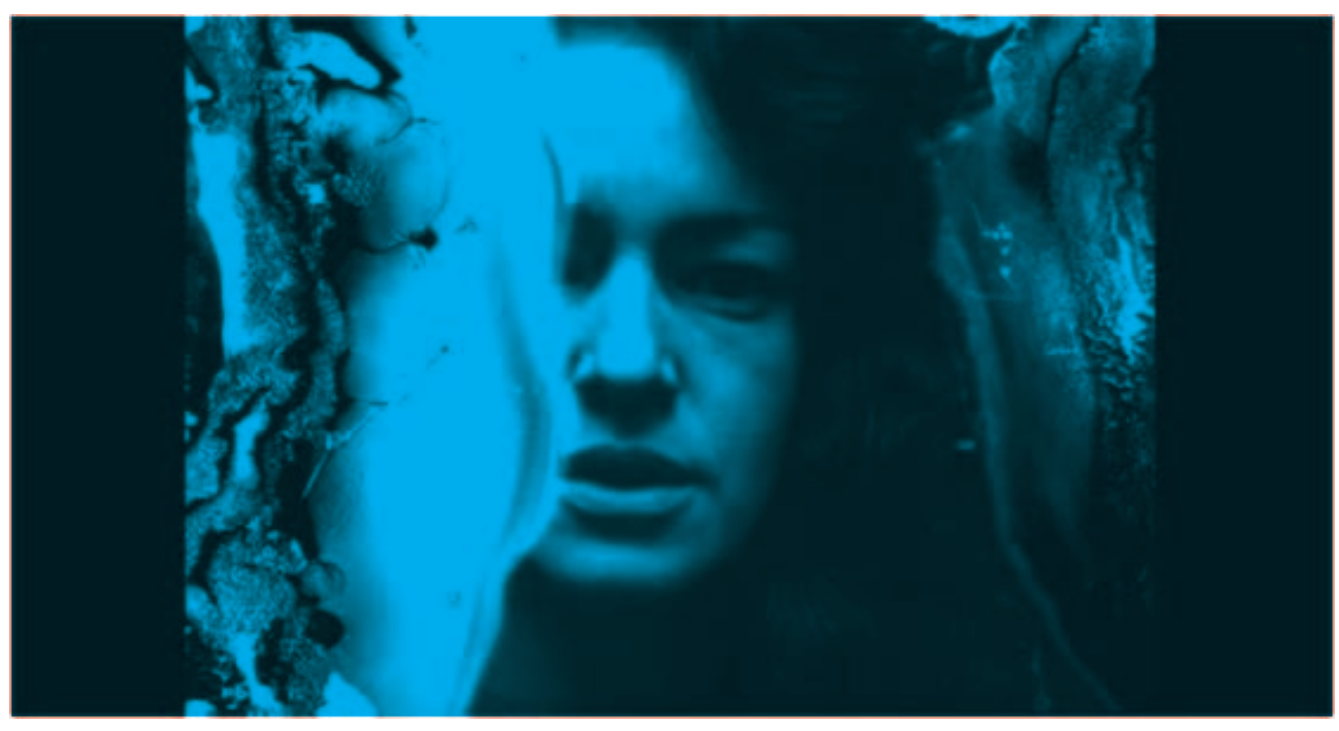


Um momento que sintetiza bem esta reflexão é um trecho aos 19 minutos quando vemos as sobras de erros de filmagem do filme Terra em transe (1967) em que Glauce olha fixamente para câmera e pronuncia: "A Fome". É neste momento do filme em que a imagem háptica se faz presente. Neste trecho a película está queimada, desgastada, suja e corroída pela má preservação. A cena é ralentada através do recurso da câmera lenta na montagem, e a parte corroída do filme invade então o rosto de Glauce, qual uma labareda que "lambe" seu rosto em um gesto tátil, a imagem "se toca", como se o tempo se fizesse presente, queimando e consumindo Glauce naquele exato instante. A imagem ganha uma organicidade, ela respira, adquire um corpo, possui uma "vida" e portanto mortalidade própria, e assim emerge enquanto superfície material constituinte.

Segundo Aumont (2000, pg. 148) "O olho vê, mas também toca: há na visão percepções óticas, puramente visuais, e percepções hápticas, visuais-táteis". O conceito "háptico" tem origem nos escritos dos historiador da arte Alöis Riegl que já diferenciava as percepção hápticas das ópticas. Este conceito será resgatado por diversos pensadores tais como Walter Benjamin, Gilles Deleuze e Félix Guattari (2000). Deleuze e Guatarri definem como "Háptica" um tipo de imagem que conclama um espaço e um modo de percepção mais tátil do que visual, uma imagem que demanda uma percepção aproximada, que se concentra na sua superfície e na textura da imagem, convocando o sentido do toque. Na visualidade háptica os olhos funcionam como órgãos de toque e não apenas como orgãos de visão, como a pele, operam pelo contato. Laura U. Marks (2000) em seu livro The skin of the film, se vale de diversos conceitos de Deleuze para analisar obras de cineastas pós-coloniais. Laura disserta sobre a diferenciação entre a imagem óptica da imagem háptica, enquanto a primeira induz o espectador a mergulhar na imagem em na sua profundidade ilusória, a segunda faz um movimento inverso de transportar o olhar do espectador para a superfície plana da imagem, expondo sua textura e materialidade plástica, fazendo um apelo ao sentidos táteis do espectador. A imagem háptica seria uma imagem sem profundidade de campo justamente distinta da imagem óptica que representa os objetos no espaço. A óptica privilegia o poder de representação da imagem, enquanto a háptica o poder de presença da imagem.

Ideia semelhante é a dupla divisão das formas de "ver" na teoria das artes plásticas, relembradas por Aumont (2000, pg.148) onde Nahsicht é a vista de perto, a visão corrente de uma forma no espaço vivido, em que é possível aproximar-se e tocar; Fernsicht é a vista de longe, a visão dessas mesma formas conforme as leis específicas da arte. Ambas as formas de 
percepção são importantes, pois é através desse movimento dialético de distanciamento e aproximação do olhar que é possível a apreensão do objeto. ${ }^{7}$ A visualidade óptica e háptica seriam, portanto, um modo de representação quanto um modo de recepção de imagens. Nesse sentido, há pintores e imagens que invocam mais uma percepção que outra, por exemplo, Francis Bacon seria um pintor-háptico, enquanto Lorrain um pintor- óptico.

O desgaste e a decomposição da película neste trecho do filme nos acionam a essa percepção háptica, uma experiência sensória, sinestésica e tátil com a imagem. Dessa forma, neste movimento centrífugo, ${ }^{8}$ a imagem desgastada pelo tempo de Glauce, salta para fora da tela, emerge para a superfície, vem à tona para o campo extra-diegético, denotando sua materialidade, sua corporeidade, a sua própria constituição enquanto imagem, abalando a estrutura mesma da representação e dos limites entre a ficção e o documental. Além disso, a estratégia da quebra da quarta parede ${ }^{9}$ nesta cena produz um jogo dialético com o espectador que abala o "efeito-fi"10 e quebra a projeção ilusionista e "mágica" da imagem óptica. Quando o filme "olha" para o espectador nesse instante reflexivo ele se percebe como tal, se dá conta de que o que está vendo se trata apenas de um filme. Confrontados pela precariedade e frontalidade da visualidade háptica, as imagens de Glauce parecem manifestar uma espécie de crise ou falência de visão renascentista, instrumental e objetiva, estamos no campo do subjetivo, da afecção (produz uma afetação emocional no espectador) e do sensorial (que faz apelo aos sentidos).

A imagem de Glauce possui uma corporeidade, tanto quanto a pessoa física pode ser tocada, arranhada, queimada, envelhecida e desgastada pelo tempo. Há no filme uma sensualidade da imagem, que invoca a "erótica da arte" de Sontag, citada anteriormente. De acordo com Laura U. Marks (2000), o modelo háptico de visão escaparia à qualificação de instrumental ou objetificante e teria uma qualidade mais propriamente "erótica". Esse erotismo viria da relação próxima, tátil e encarnada que a visualidade háptica encoraja. Nela o espectador é convidado a se aproximar do corpo da imagem, através de um olhar íntimo e detalhado. Aqui, trata-se, antes de tudo, de acariciar, de tocar a imagem e não de compreendê-la. Glauce, como celebridade e estrela de cinema fetichizada ${ }^{11}$ é desejada pelo espectador-voyeur que anseia por tocá-la, em cenas sensuais e eróticas da atriz (como a cena de amor na praia e a que ela come frutas, nua na cama), há nesse trecho, talvez, um comentário crítico à indústria do entretenimento e do espetáculo que de certa forma "usou e abusou", consumiu e desgastou Glauce com o passar dos anos. 
O filme termina como se inicia, com a voz de Glauce ensaiando. Embarcamos numa viagem circular, uma travessia pela carreira de Glauce, espécie de tempo-ourobourus saído do Aleph de Borges (1949), ${ }^{12}$ escapando da lógica da narrativa cronológica de um tempo linear. No decorrer do filme não há uma preocupação em localizar os diferentes filmes em que Glauce atuou, não há utilização de legendas contextualizando os filmes e suas datas, evita-se, dessa forma, colocar Glauce em um passado distante, dentro de um discurso memorialista, nostálgico em tom póstumo de homenagem. Não estamos olhando para um arquivo-morto, mas sim habitando outro território-sensível, uma paisagem-poética distinta, uma imagem-afecção ${ }^{13}$ dentro de um universo imaginário de Glauce Rocha, figura mítica que continua a ressoar e afetar o presente, imagem que possui uma perenidade física mas que ficará sempre na zona limítrofe entre passado e o presente. Assim, a percepção háptica transforma o rosto de Glauce em uma espécie de imagem-objeto, imagem-corpo, mas também por sua característica auto-reflexiva e metalinguística uma imagem-pensamento, imagem-metafísica que coloca em questão a sua própria constituição enquanto tal.

Ao final do filme fica no ar a pergunta inicial: mas afinal quem era Glauce Rocha? Vemos Glauce em diversas situações: nua, velha, jovem, prostituta, recatada, guerrilheira, intelectual, bela, triste, alegre, humilhada, elegante, decadente. Quem é esta mulher que o espectador (parece) conhecer tão bem, com tanta intimidade quase a ponto de tocá-la? Quando Agamben (1996) disserta sobre o Rosto e a Rostidade de Deleuze ele diz:

Isso que o rosto expõe e revela, não é qualquer coisa que possa ser formulada nessa ou naquela proposição significante, nem mesmo é um segredo destinado a restar para sempre incomunicável. A revelação do rosto é a revelação da própria linguagem. Essa não tem, consequentemente, nenhum conteúdo real, (...) é unicamente abertura, unicamente comunicabilidade. Caminhar pela luz do rosto significa ser essa abertura, padecer dela. Assim, o rosto é, sobretudo, paixão da revelação, paixão da linguagem. (AGAMBEM, 1996: 74-80)

Uma conclusão que o filme nos permite a de que não existe uma visão que possa dar conta da figura e rosto emblemáticos de Glauce Rocha em sua totalidade, estamos diante de uma imagem, de uma paisagem imaginária e imagética abertos às possibilidades da linguagem e da representação talvez a única resposta possível seja a de Godard: "Ce n'est pas une image juste, c'est juste une image."14 


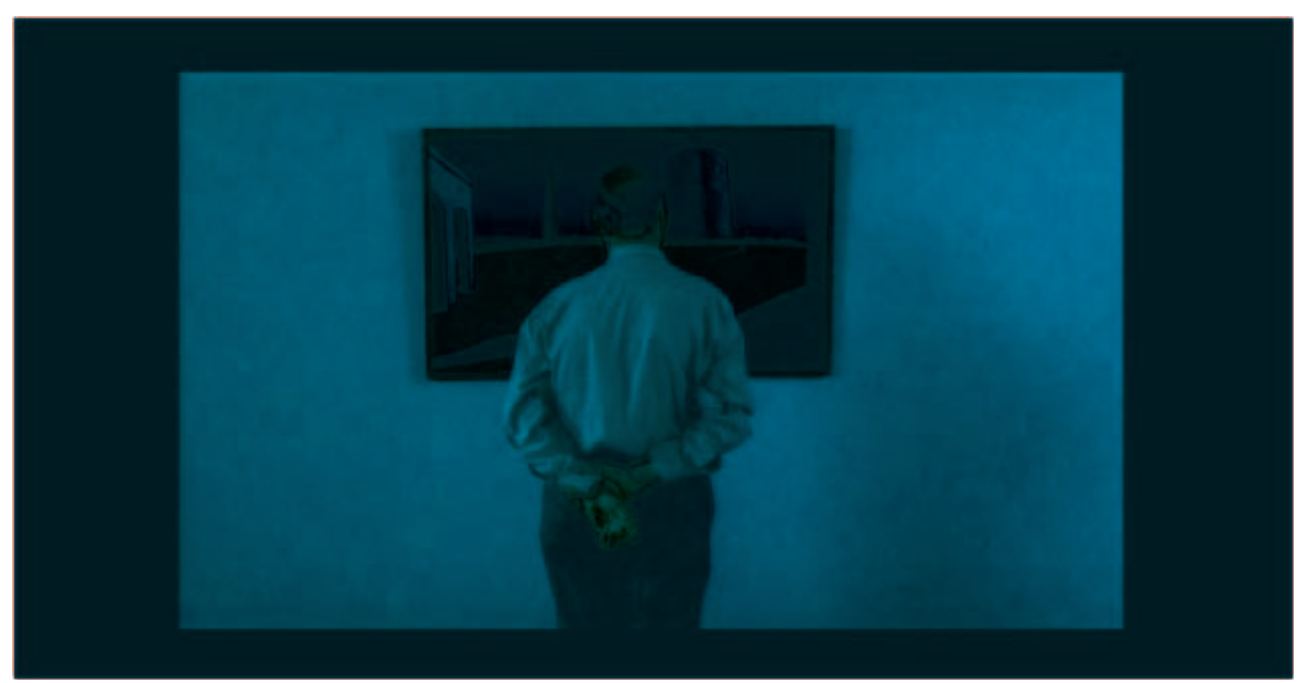

\section{Enigma de um dia (1996)}

Na primeira cena de Enigma de um dia (1996) vários visitantes de um museu param diante da câmera, eles contemplam por um momento a tela e em seguida tecem comentários acerca do que veem. Logo percebemos que se trata do ponto de vista da obra de arte, um enquadramento que simula uma visão "subjetiva" de um quadro pendurado na sala de exibição que olha para o seu público: o olhar do quadro de Giorgio de Chirico, homônimo do filme. O vigia do museu (Leonardo Villar), personagem principal da trama, figura aparentemente menos "instruída" do ambiente é, porém a que é mais afetada pela obra do pintor italiano. Após o encontro com o quadro ele passa a carregar dentro de si aquele "bloco de sensações," um "composto de afectos e perceptos" (Deleuze \& Guatarri, 1992, pg. 193) que o impacta de tal forma que passa a modificar o seu entorno, seu cotidiano, seu olhar e sua relação com o mundo. Os lugares por onde passa na grande São Paulo vão lentamente ganhando cores, tonalidades, formas e arquitetura que remetem às paisagens oníricas, melancólicas e vazias do universo metafísico de De Chirico, expressas na bela fotografia de Mário Carneiro. 
Já na abertura nota-se novamente o caráter auto-reflexivo e metalinguístico dos filmes de Pizzini. O personagem principal da narrativa é o vigia do museu, mas bem poderia ser o próprio quadro de De Chirico. No filme, o mundo é visto através do quadro e da obra de arte, que rapidamente nos remete a metáfora do cinema enquanto janela do mundo. ${ }^{15} \mathrm{O}$ filme de Pizzini ao evocar a sua própria moldura, novamente, como em Glauces-estudo de um rosto (2001) opera no movimento dialético de dentro e fora da obra, pois expõem sua própria condição enquanto cinema e obra de arte (janela do mundo - efeito-fi), colocando o espectador numa dinâmica entre o diegético e o extra-diegético, transitando entre as dicotomias da superfície e profundidade, do virtual e real, e da transparência e opacidade, do óptico e do háptico, da aproximação e do distanciamento. Como na fita de Moebius, os lados contrários nunca se tocam, entretanto um é a continuação do outro, dependem um do outro para coexistirem como forma coesa, é uma obra que se constitui como dobra sobre si mesma, provocando uma experiência sensória com a imagem e uma reflexão acerca do próprio meio.

Segundo sinopse oficial o filme se passa "no instante em que o vigia do museu vê e é visto pelo quadro" é, portanto, um filme sobre o afeto, ou seja: a afetação causada no encontro entre a obra de arte e seu espectador. Em sintonia com o pensamento de Didi-Huberman (2010) que, em seus ensaios sobre a obra do artista minimalista Tony Smith, conceitualiza que toda obra de arte nos convoca a estar Diante e Dentro dela de forma simultânea e paradoxal, posto que toda imagem que olhamos nos olha de volta refletidamente:

E diante da imagem - se chamarmos imagem o objeto aqui do ver e do olhar - todos estão como diante de uma porta aberta dentro da qual não se pode passar, não se pode entrar (...) Olhar seria compreender que a imagem é estruturada como um diante-dentro: inacessível e impondo sua distância, por próxima que seja - pois é a distância de um contato suspenso, de uma impossível relação de carne a carne. Isso quer dizer exatamente - e de uma maneira que não é apenas alegórica - que a imagem é estruturada como um limiar. Uma trama singular de espaço aberto e fechado ao mesmo tempo. (HUBERMAN, 2010: 243).

O vigia (que pode representar a todos nós espectadores) é colocado justamente diante dessa porta, nesta brecha, nesta zona limite entre a vida e a arte, nessa fronteira um entre-território estranho, justamente no limiar citado por Huberman. Ele olha para a obra e é contaminado por ela. A polinização entre os dois mundos se intensifica a tal ponto que, em um determinado momento da narrativa, já não sabemos se o que estamos assistindo é a projeção imaginária 
do vigia para dentro da pintura (espécie de sonho-acordado do protagonista), uma de suas paisagens-interiores que transbordaram para realidade ou se, de fato, se trata de seu cotidiano na cidade de São Paulo.

O plano mais intrigante que destoa dos demais é a imagem de arquivo em preto e branco de trilhos filmadas do ponto de vista de um maquinista de um trem em movimento. É uma imagem antiga, já desgastada pelo tempo, suja e repleta de ruídos que nos relembra os primórdios do Cinema e seu nascimento histórico: a Chegada de um trem a estação de la Ciotat (1895), dos irmãos Lumiére, o Grande roubo do trem (1903), A General (1926) de Buster Keaton, etc. ${ }^{16}$ Esta imagem analógica vinda de um aparato cinematográfico obsoleto do passado, novamente nos remete a visualidade háptica. A visualidade háptica para Laura U. Marks (2000) está sempre envolta em mistério, pois é uma imagem que vem na forma de vestígio ou de esboço, que recusa a clareza, organização, controle e limpeza da imagem-óptica, portanto se torna difícil de interpretar, convidando o espectador a completá-la experimentando-a através dos seus sentidos, se utilizando de outras ferramentas que não a razão, a interpretação e cognição (a hermenêutica). 
Além disso, para Marks, na imagem háptica ocorre justamente esse entrelaçamento entre sujeito e objeto, uma relação de abandono do sujeito no contato com o outro que é da ordem do sensorial e do erótico. Esta seria uma definição básica do erotismo: a capacidade de oscilar, de se mover entre o doar-se e o receber, entre o abandono e o controle de si.

O que é erótico na visualidade háptica, então, pode ser descrito como o respeito pela alteridade, e a concomitante perda de si na presença do outro. Erotismo é o encontro com um outro que se delicia diante de sua alteridade, mais do que tenta conhecê-la. O erotismo visual possibilita à coisa vista manter sua incognoscibilidade, se deliciando em jogar na fronteira do cognoscível. O erotismo visual permite ao objeto da visão permanecer insondável. (Marks apud Gonçalves, 2002, pg. 20):

No final do filme, observa-se no quadro de De Chirico um pequeno trem que passa ao fundo no horizonte. Neste movimento "erótico", a imagem analógica corroída pelo tempo nos faz mergulhar no topos cinematográfico, na sensualidade da matéria fílmica. Como se fosse possível, por alguns segundos, ser transportado (pelo trem) para dentro da tela, uma imersão centrípeta para um outro espaço-tempo, habitamos o território-sensorial do interior mesmo da obra de arte. Semelhante a parábola de Kafka em O processo conforme citada por Huberman (onde curiosamente há também a personagem do Vigia) "espiamos" o que nos aguarda do outro lado da porta eternamente intransponível.

Segundo Gene Youngblood (1970), o cinema expandido seria essencialmente sinestésico. "O cinema sinestésico é espaço e tempo contínuo. (...) Sinestésica é a harmonia dos impulsos diferentes ou opostos produzidos por uma obra de arte. Isso significa a percepção simultânea de opostos harmônicas"(YOUNGBLOOD, 1970). Para o autor, as imagens de um cinema expandido são capazes de criar uma nova forma de percepção do tempo que não faz mais parte de uma tradicional narrativa clássica, e sim transitam entre diferentes dimensões temporais que se interconectam, e coabitam diferentes temporalidades e materialidades. Este tempo heteróclito, múltiplo, caótico e policrônico, foge a ordem cronológica, linear, com um começo, meio e fim. Um tempo que segundo Deleuze seria da ordem da alucinação, da imanência e do devir. ${ }^{17}$ Assim, a escolha de Pizzini por trabalhar com imagens analógicas, se configura como forma de expressão essencialmente contemporânea, por ser híbrida; se voltando para 
o passado, se apropriando dele e re-experimentando-o, convocando uma percepção háptica, experimental, que conjuga diferentes tempos, materialidades e sensorialidade em um mesmo objeto, uma obra que merece um olhar mais atento e aprofundado.

Artigo recebido em julho de 2016 e aprovado em agosto de 2016.

\section{Notas}

1 No livro "Empirismo Hereje" há um artigo intitulado "O Cinema de Poesia" em que Pasolini disserta com mais detalhe sobre esse "gênero" de cinema. PASOLINI, P. P. Empirismo hereje. Trad. Miguel S. Pereira. Lisboa: Assírio \& Alvim, 1982. pg 137.

2 Alguns outros elementos que caracterizam o filme como pertencente ao gênero Cinema de Poesia para Pasolini são: a "imobilidade do plano", que Pasolini elogia em Antonioni, o "cinema sob o cinema" quando ocorre o uso da intertextualidade e da metalinguagem em filmes, a utilização de vários suportes (filme, vídeo, fotografia) e a manipulação ostensiva do ponto de vista narrativo.

3 Disponível em: http://telatela.cartacapital.com.br/joel-pizzini-eu-acredito-na-sensualidade-da-materia-do-cinema/

4 Disponível em: http://www3.folhape.com.br/cms/opencms/folhape/pt/cultura/noticias/arqs/2016/02/0301.html

5 Conceitualizado de diferentes maneiras ao longo das décadas, o artista pós-moderno e seu campo de trabalho foi primeiramente definido pelo termo "Campo Ampliado" cunhado por Rosalind Krauss (em seu livro "Escultura no Campo Ampliado" de 1969) ao analisar o trabalho de uma geração de artistas americanos dos anos 60-70 tais como: Robert Morris, Joel Shapiro, Richard Serra, Bruce Nauman e Sol Lewitt.

60 termo "cinema expandido" foi cunhado em 1970 por Gene Youngblood. No livro homônimo Youngblood procura dar conta de uma série de experiências híbridas do cinema com tecnologias incipientes tais como o video, o fax, o xerox, os computadores; à luz da teoria cibernética e de uma aposta utópica na indistinção entre arte e vida. Atualmente, o termo vem sendo utilizado de modo menos "idealizado" para se referir a um conjunto de obras que problematizam o cinema tradicional na esfera da arte, notadamente as experiências de videoarte, instalações e filmes experimentais realizados a partir da década de 60.

7 Uma ideia também defendida por Laura U. Marks no final do seu artigo: "Haptic visuality, touching with the eyes".

8 Nos apropriamos deste conceito a partir dos escritos de Bazin "O quadro pictórico é, portanto, centrípeto, orientado para o interior. Ao contrário, tudo que é projetado na tela é necessariamente, em função de sua natureza fotográfica, percebido como indefinido, assimilado ao mundo exterior. A tela não é mais um quadro, mas um refúgio; ou, se quisermos, uma janela; ou, se quisermos ainda, um espelho. Ela é centrífuga, pois a imagem se prolonga virtualmente sem limite para além do retângulo negro que restringe nossa visão. Em outros termos, a fotografia e a fortiori o cinema nos mostram sempre um fragmento do universo." Proposta do dramaturgo de vanguarda Bertold Brecht que através da quebra da separação entre público e atores, busca uma dialética que "acordaria" politicamente o espectador passivo. Pratica será adotada pela Nouvelle Vague francesa quando Godard e Truffaut colocam seus atores olhando para a câmera, bem como no Cinema Novo e Marginal. Esta concepção Brechtniana de um espectador "passivo" será refutada no contemporâneo por diversos autores, tais como Rancière em 'Espectador Emancipado"(2014). 
9 Proposta do dramaturgo de vanguarda Bertold Brecht que através da quebra da separação entre público e atores, busca uma dialética que "acordaria" politicamente o espectador passivo. Pratica será adotada pela Nouvelle Vague francesa quando Godard e Truffaut colocam seus atores olhando para a câmera, bem como no Cinema Novo e Marginal. Esta concepção Brechtniana de um espectador "passivo" será refutada no contemporâneo por diversos autores, tais como Rancière em 'Espectador Emancipado" (2014).

10 Condição de submotricidade em que o público "domesticado", silencioso e imóvel diante da tela "mergulha" por horas na ilusão da narrativa das imagens em movimento. Teoria da Gestalt, conceituada por Hugo Münsterberg e Rudolf Arnheim.

11 Laura U. Marks (2000: 84-85) também disserta em seu livro sobre o fetiche das imagens. Para ela o objeto de fetiche tem necessariamente uma relação indexical de contato com o originário referente, possuindo assim a "aura" de um objeto e/ou cultura. Ela retira suas teorias de W. Benjamin, na corrente marxista-psicanalista, considera que o objeto fetichizado codifica verdades sociais e culturais e que só podem ser descobertas através de um choque que atinge o inconsciente.

12 Ouroboros (ou oroboro ou ainda uróboro) é um símbolo representado por uma serpente, ou um dragão, que morde a própria cauda. O nome vem do grego antigo: $\square$ (oura) significa "cauda" e e (boros), que significa "devora". Assim, a palavra designa "aquele que devora a própria cauda". Sua representação simboliza a eternidade. O Aleph é um livro de histórias curtas de Jorge Luis Borges, publicado em 1949 e contendo, entre outros, o conto que dá nome ao livro. O escritor aborda vários pontos paradoxais como a imortalidade, a identidade, o duplo, a eternidade, o tempo, a soberba, a condição humana e suas crenças.

13 Enquadramento em primeiro plano (close): "A imagem-afecção é o primeiro plano, e o primeiro plano é o rosto..." (Deleuze, 1985: 114).

14 “Não é uma imagem justa, é justo uma imagem". Tradução de Peter Pál Pelbart.

15 Segundo Ilana Feldman (2011) "a metáfora da janela orienta diversos regimes de visibilidade (a pintura, o cinema e até a televisão) desde a Renascença, com a invenção da perspectiva e a composição, por Alberti, do quadro como "janela aberta ao mundo". (..) Supondo um lugar calculado para o espectador, a perspectiva, o palco italiano do teatro (sobretudo pós-Diderot) e o cinema clássico narrativo faz da distância e da separação entre observador e observado, entre realidade e espetáculo, a base do regime "representativo" da arte. É a partir de tal separação, condição da representação clássica, que o espectador pode enfim mergulhar no mundo de dentro da tela a partir da identificação e do "efeito janela"(...).

16 O trem é figura de linguagem muito recorrente também na filmografia de Yasujiro Ozu, que o utiliza como metáfora para industrialização e ocidentalização do Japão.

17 “(...) em Deleuze, ao invés de uma linha do tempo, temos um emaranhado do tempo; em vez de um fluxo do tempo, veremos surgir uma massa de tempo; em lugar de um rio do tempo, um labirinto do tempo. Ou ainda, não mais um círculo do tempo, porém um turbilhão, já não uma ordem do tempo, mas uma variação infinita, nem mesmo uma forma do tempo, mas um tempo informal, plástico. Com isto, estaríamos mais próximos, sem dúvida, de um tempo da alucinação do que de uma consciência do tempo." (Pelbart apud Marchesini, 2004, XXI).

\section{Referências}

AGAMBEN, Giorgio. O que é o Contemporâneo? e outros ensaios. Tradução: Vinicius Nicastro Honesko Ed. Argos, Chapeco, SC, 2009.

AGAMBEN, Giorgio. II volto. In: Mezzi senza fine. Note sulla politica. Bollati Boringhieri: Tradução de Murilo Duarte Costa Corrêa Torino, 1996, p. 74-80.* 
AUMONT. Jacques. O Olho Interminável: Cinema e Pintura. Tradução Eloisa Araujo Ribeiro. São Paulo: Cosac \& Naify, 2004.

BAZIN, Andre. O que é o Cinema. Editora Cosac \& Naify; 1a Edição. 2014

BORGES, Jorge Luis. O Aleph. Tradução de Davi Arrigucci Junior. Ed. Companhia das Letras. 2008. Sao Paulo.

DELEUZE, G; GuATTARI, F. Percepto, Afeto e Conceito. In: O que é a filosofia?Tradução: Bento Prado Jr e Alberto Alonso Muñoz. Rio de Janeiro: 34, 1992

DELEUZE, G; GUATTARI, F Mil platôs - capitalismo c esquizofrenia, vol. 3 / tradução de Aurélio Guerra Neto et alii. — Rio de Janeiro: Ed. 34, 1996 (Coleção TRANS)

DIDI-HUBERMAN. O que vemos, o que nos olha. Tradução: Paulo Neves São Paulo: Editora 34. 2010.

GUMBRECHT, Hans U. Production of Presence. California: Stanford University Press, 2004

GONÇALVES, Osmar (org.) Narrativas Sensoriais $1^{\text {a }}$ ed. - Rio de Janeiro: Editora Circuito, 2014.

GONÇALVES, Osmar Reconfigurações do olhar: o háptico na cultura visual contemporânea em VISUALIDADES, Goiânia v.10 n.2 p. 75-89, jul-dez 2012

FELDMAN, Ilana Através da janela: o cinema de Perlov, Akerman e Farocki. Anais Socine 2011.

MARKS, Laura. The skin of the Film. Intercultural Cinema, Embodiment and the Senses. Duke University Press. Durham and London. 2000.

PASOLINI, P. P. Empirismo hereje. Trad. Miguel S. Pereira. Lisboa: Assírio \& Alvim, 1982.

PELBART, P. Peter O Tempo Não-Reconcliliado. Imagens do Tempo em Deleuze. São Paulo, Perspectiva, 2004.

RANCIÉRE, Jacques Espectador Emancipado. Tradução Ivone C. Benedetti. $2^{a}$ Ed. São Paulo. Martins Fontes , 2014

SONTAG, Susan. Against Interpretation and other Essays. Ed. Anchor; Reprint edition 1990

SASSOON, Joanna. Photographic Materiality In: The Age Of Digital Reproduction In Photographs Objects Histories - On The Materiality Of Images. Ed. Routledge, 2004.

YOUNGBLOOD Gene; Expanded Cinema. A Dutton Paperback. P. Dutton \& Co., Inc., New York, 1970. 